\title{
Some Realism About Rulism: A Parable for the Fiftieth Anniversary of the Federal Rules of Civil Procedure
}

\section{Citation}

Martha Minow, Some Realism About Rulism: A Parable for the Fiftieth Anniversary of the Federal Rules of Civil Procedure, 137 U. Pa. L. Rev. 2249 (1989).

\section{Published Version}

http://scholarship.law.upenn.edu/cgi/viewcontent.cgi?article=3881\&context=penn_law_review

\section{Permanent link}

http://nrs.harvard.edu/urn-3:HUL.InstRepos:12795542

\section{Terms of Use}

This article was downloaded from Harvard University's DASH repository, and is made available under the terms and conditions applicable to Other Posted Material, as set forth at http:// nrs.harvard.edu/urn-3:HUL.InstRepos:dash.current.terms-of-use\#LAA

\section{Share Your Story}

The Harvard community has made this article openly available.

Please share how this access benefits you. Submit a story.

Accessibility 


\title{
GOMMENTARY
}

\author{
SOME REALISM ABOUT RULISM: \\ A PARABLE FOR THE FIFTIETH ANNIVERSARY OF THE \\ FEDERAL RULES OF GIVIL PROGEDURE
}

\section{Martha Minow $\dagger$}

In 1938, Orson Welles created widespread panic when he produced a radio broadcast of H.G. Wells' War of the Worlds. ${ }^{1}$ In the same year, Marjorie Kennan Rawlings wrote The Yearling. Thornton Wilder wrote Our Town. Richard Wright produced Uncle Tom's Children. John Dewey published Logic: The Theory of Inquiry, and Experience and Education. Alfred Hitchcock made a movie called The Lady Vanishes. John Rockefeller endowed the Cloisters and thus gave New York its own medieval world. "A Tisket, A Tasket" hit the pops chart in the music business, as did "Jeepers, Creepers" and "You Must Have Been a Beautiful Baby." Also in 1938, the lawyer, Clarence Darrow, died. The United States Supreme Court ordered the University of Missouri Law School to admit blacks because there were no separate, much less equal, facilities in the area that would admit them. New York won the World Series against Chicago. A man in Hungary invented the ball-point pen. ${ }^{2}$ The Nestle company created the first Nestle Toll House Morsel. ${ }^{3}$ And the federal courts got their own Federal Rules of Civil Procedure.

Less well known, perhaps, is another event, which is equally momentous, even if fictional. Indeed, this event provides a metaphor for us to consider as we look back across these fifty years. Imagine that fifty years ago, a liberal reform movement swept through a university whose name I will conceal in order to maintain the proper parablic tone.

The reform was actually decades in coming. Members of the university community-and others-debated whether the process of education was too formal and rigid. Reformers claimed that the admission

$\dagger$ Professor of Law, Harvard Law School.

1 Unless otherwise indicated, the information in this paragraph is gleaned from $B$. Grun, The Timetables of History 514-15 (1979).

${ }^{2}$ His name was Lajos Biro.

3 See NewSWEEK, Sept. 26, 1988, at 77. 
process was too exclusionary, the examinations produced undue surprise and excessive competition among students rather than substantive learning, the required curriculum was antiquated, and the students were stifled rather than encouraged to tailor their own educational programs.

So, after much debate, the university adopted a new set of rules. First, the rules changed the admissions process: a new commitment to open access lowered the minimum application standards. Some critics claimed this meant essentially open enrollment and would bring in too many and too unqualified students. The defenders of the change said no, the applicant did have to produce a short and plain statement showing that she is entitled to admission. ${ }^{4}$

Second, in response to the charges of undue surprise at exam time and excessive competition among the students, the university adopted many new rules that it called, in a fit of creativity, rules $26-37.5$ These rules introduced the idea that education includes a process of discovery. They ended closed book examinations, and allowed students to consult any and all materials during exam time. They allowed open-book exams that could engage the students in a learning process for extended periods of time. And the rules, in a truly innovative stroke, allowed any individual student, in preparing for exams, to obtain material possessed or developed by other students. Any class notes gathered by one student could be obtained, through requests for production, by another student. Students who failed to cooperate with this commitment to discovering and sharing study materials could be sanctioned by the school.

Third, the university acknowledged a need for curricular change, but concluded that this involved substantive reforms that would require the assistance of another process, beyond the revision of administrative rules. In the meantime, the university adopted a flexible rule which allowed individualized conferences before the start of courses. These conferences would bring together students and administrators to discuss how each student could proceed without wasting time--through greater planning of the subjects to be studied and the time frame for that study. ${ }^{6}$

Finally, to encourage student initiative, the university adopted a bundle of innovative rules. One rule allowed students to band together to start their own courses if they could find a group that shared sufficiently common interests and if they could show that designated repre-

4 Cf. FED. R. GIv. P. 8(a)(2) (permitting pleadings that set forth "a short and plain statement of the claim showing that the pleader is entitled to relief").

- Cf. FED. R. Crv. P. 26-37 (the discovery rules).

6 Cf. FED. R. Crv. P. 16 (pretrial conferences, scheduling, and management). 
sentatives who designed the course adequately represented the interests of the entire group. ${ }^{7}$ Another rule allowed individual students to join with a few others to construct more limited study plans and, indeed, to structure their education according to their own designs. ${ }^{8}$

In short, the 1938 rules marked a commitment to overcome archaic formalities standing in the way of learning. They showed a commitment to flexibility, open access, cooperation, shared information, informal education planning, and student-initiated learning. All of these changes were prefaced by a lyrical rule assuring students that they were each entitled to an educational, speedy, and inexpensive course of study. ${ }^{9}$ Most students interpreted this cardinal rule as a mandate to lobby the registrar and other administrators on any matter that they found unfair or inefficient in their experience at the university. The university administrators-and, most notably, the reformers-hoped that competitive student gamesmanship would fall by the wayside in the kinder, warmer regime, and that real learning would be promoted and set free from bureaucratic interference.

Time passed. So did some hopes. An early wave of disillusionment rolled over campus, as students started to use the discovery process not to advance their own learning, but to take advantage of the hard work of others. Students even sought to obtain the study guides and outlines others assembled rather than preparing for examinations by themselves. A brief skirmish on this issue, involving a student named Hickman, ${ }^{10}$ led to a new revision of the discovery rules ${ }^{11}$ allowing each student to keep her own private exam-preparation materials. The event quieted the initial exuberance on campus in the wake of the new rules. Still, these were the golden days, in a golden era. Faculty and students alike celebrated and expanded the possibilities of student-initiated courses. ${ }^{12}$

The real problems awaited a decade called the 1970s. An upsurge of competitiveness among students, perhaps accompanying the babyboom generation, produced a flood of applications, swelling the ranks of the university and bringing about cut-throat study practices. Students hid materials in the library and made time-consuming discovery re-

7 Cf. Fed. R. Giv. P. 23 (class actions).

${ }^{8}$ Cf. FED. R. Grv. P. 14, 19-20, 22 (third-party practice, joinder, and interpleader, respectively).

- Cf. FED. R. Giv. P. 1 (stating that the Rules "shall be construed to secure the just, speedy, and inexpensive determination of every action").

${ }^{10}$ Cf. Hickman v. Taylor, 329 U.S. 495 (1947) (addressing the issue of whether attorneys have a right to obtain and use witness statements recorded by opposing counsel).

${ }^{11} C f$. Fed. R. Grv. P. 26(b)(3) (defining limits on discovery).

12 Cf. FED. R. Crv. P. 23 (class action rule, expanded in 1966). 
quests to distract their. fellow students and obtain an advantage in the great grade grab. At the same time, the costs of higher education escalated exponentially, and students, faculty, and parents all scrambled to devise ways to shift the costs to someone else. A series of new changes arose on campus, some officially and some unofficially.

First, to deal with the rising numbers of applicants, the university retained its generous admissions standards, but decided to increase its flunk-out rate through stringent application of an old rule allowing mid-term summary judgments. ${ }^{13}$ Similarly, the administration tried to crack down on abuses of the students' discovery process, regulating redundant and excessive requests. ${ }^{14}$ Further, in a surprisingly virulent move, the administration authorized individual faculty members to punish students for failing to prepare adequately for class or otherwise irritating fellow students or the faculty. ${ }^{15}$ One notorious teacher even talked about sanctioning parents if a student appeared notably ill-prepared or ill-mannered. ${ }^{16}$

Other, less formal changes also occurred. Individual faculty members imposed stringent requirements about due dates for term papers. And faculty members began to use the occasion of the informal studentfaculty pre-term conferences to pressure students to take certain courses and drop others. Some faculty members even used the conferences to urge some students to drop out of school altogether. ${ }^{17}$ A particularly energetic group of faculty members named themselves the shepherds and devised what they called the student management system, steering students through the university with an eye on the total cost and efficiency record in handling large numbers of young people. ${ }^{18}$ The school also introduced a tracking system. Students received assessments that placed them on one of three tracks as they made their way through the

13 Cf. Celotex Corp. v. Catrett, 477 U.S. 317 (1986) (setting forth liberal standard for grants of summary judgment).

${ }^{14}$ Cf. FED. R. Civ. P. 37 (discovery sanctions).

15 Cf. FED. R. Crv. P. 11 (providing for sanctions against attorneys or parties for pleadings, motion, or other papers signed in violation of requisite basis in fact and law). Cf. generally Burbank, The Transformation of American Civil Procedure: The Example of Rule 11, 137 U. PA. L. REv. 1925 (1989).

${ }^{16}$ Cf. Carter, The Federal Rules of Civil Procedure as a Vindicator of Civil Rights, 137 U. PA. L. REv. 2179, 2194 \& n.76 (1989) (recounting the imposition of $\$ 54,000$ in sanctions upon an NAACP-affiliated attorney after the court had decided a series of summary judgments in favor of the attorney).

17 Cf. Shapiro, Federal Rule 16: A Look at the Theory and Practice of Rule making, 137 U. PA. L. REv. 1969, 1981-82 (1989) (arguing that some have viewed Rule 16 as an invitation to encourage disposition of marginal issues without trial).

18 Cf. Keeton, Time Limits as Incentives in an Adversary System, 137 U. PA. L. Rev. 2053, $2057-58$ (1989) (describing judges as "shepherds" rather than as "managers"). 
school: honors, regular, and messy. The honors students were encouraged to speed through school, even to get ahead on wait lists for popular courses. Regulars were placed on a slower track. The messies were assigned to the most boring and tedious courses; many of them, over time, dropped out.

Now, students found the extraordinary costs of attending the university compounded by the costs, in time and money, presented by these procedural rules. Some became bitter over the contrast between the ideas they had read about in the university catalogs and their actual educational experiences. Students in the business school launched forprofit alternative schools housed just outside the campus. They employed retired professors to offer compressed courses for a fee, and then encouraged students either to seek official credit through university achievement exams, or to settle for sheer educational value rather than official recognition of their work. Especially wealthy students found it possible to rent their own professors and establish by contract private education tailored to their own needs.

The university caught wind of this successful ADR program (or Alternative Dissemination Research, as the business school students called it). Falling into the free market mood, the university decided to offer comparable mini-courses, and convince students that these would be worth an extra tuition charge, deemed a "user fee." Some teachers followed suit in their own ways and established forms of contract learning within the university. One devised what she called "standing orders," including this one: "In my classroom, you are allowed to ask only ten questions during the semester, so you had better make them good ones." Others counseled some students to find alternative educational programs before enrolling full-time in the university; some professors encouraged vocational training, while others pointed to correspondence schools. ${ }^{18}$

The entire university's budgetary burdens led to a decision to make greater use of teaching assistants and other adjunct staff. In very large courses, some students began to encounter a hierarchy of a teaching assistant first, then a head teaching fellow, and then a secretary, before ever gaining access to the professor herself. But it was not clear to anyone whether this pattern yielded a lower quality of education. ${ }^{20}$

${ }^{19}$ Cf. Mathews v. Eldridge, 424 U.S. 319, 336-37 n. 15 (1976) (stating that due process requirements are "flexible"); Friendly, "Some Kind of Hearing," 123 U. PA. L. REv. 1267, 1279-95 (1975) (discussing whether little more than exchanges of paper could amount to a due process hearing).

${ }^{20} \mathrm{Cf}$. Silberman, Judicial Adjuncts Revisited: The Proliferation of Ad Hoc Procedure, 137 U. PA. L. REv. 2131, 2174 (1989) (noting that although judicial adjuncts do not serve the functions envisioned in 1938 , there have been some benefits from their 
Some teaching assistants seemed more sensible than some professors, and more responsive to student needs.

Still, there was a growing sense that, without much deliberation, the university had undergone a counter-revolution. It was not a complete reversal or return to the days of restricted access to the university, antiquated curriculum, surprise in the exams, and stifled student creativity. But some of those same problems seemed to reappear in new guises. Tracking, the use of teaching assistants, and pressure to leave the university and to use cheaper, instructional alternatives in many ways undermined the ideals of open access. Paradoxically, perhaps, the commitment to broadening educational opportunities drew a larger number of people within the university, but then the university responded by creating separate educational programs, and even by steering some students away from formal schooling. The possibility of midyear flunk-outs and sanctioning by teachers added velocity to the already growing intensity of student competition and gamesmanship, while increasing the power of the faculty. ${ }^{21}$ In the name of efficiency and good management, the university introduced greater bureaucracy, and the ideal of fair and inexpensive education, shaped by student initiative, seemed more remote than ever.

The university scheduled a celebration for the fiftieth year following its 1938 reforms, but as the time for the celebration grew near, students and teachers alike began to formulate grievances rather than compose praises. Some raised issues that no one had discussed for some time. Could a curriculum geared toward national issues adequately prepare people for local careers? Is the university really for everyone? Should the same format of classroom lectures, term papers, and final examinations accompany each course? Would it be possible to develop alternatives to this most expensive form of residential education, perhaps through greater enrollment of commuter students and through cooperative education, alternating paid work and classroom experience? Could new technologies provide better alternatives for sharing information and individualizing the learning process?

Others charged that departures from the vision of the 1938 reforms, and the apparent counter-revolution, had little to do with any announced rules and more to do with the culture and character of the students. One wise soul was heard to say, "the traditional competitive

use, such as the development of "innovative procedures to streamline and expedite cases").

${ }^{21}$ Cf. Rosenberg, Federal Rules of Civil Procedure in Action: Assessing Their Impact, 137 U. PA. L. Rev. 2197, 2207-09 (1989) (discussing the increase in judicial power under the Federal Rules). 
education is governed more by tradition than by rule."22 Merely changing the university rules would not change students' customs or traditions, including such disreputable behavior as book-stealing and notehoarding. Some professors cited the declining self-restraint by students, caught up in a frenzy of rivalry and mutual distrust. One observer commented that as enrollment grew, fewer students knew one another and few felt any duty to respect one another, or even to respect the learning process, in their scramble for success. Another noted that any educational system will be manipulated by the ingenuity of its students. ${ }^{23}$

Still others claimed that the recent changes in the university imposed a disproportionate, negative impact on minority students. Members of racial and ethnic groups, along with white women, who had not been represented much in earlier classes at the university, indeed began to enroll in large numbers during the 1970s and 1980s. It seemed odd that just as they started to appear in large numbers on campus, the rules of the university changed; the flunk-out rate escalated, teacher discretion to issue sanctions grew, tracking and bureaucratized educational programs arose, and pressure for students to pursue alternative educational options outside the university mounted. But the politics of all these changes seemed difficult to discern. All the official reforms had ostensibly neutral justifications pertaining to efficiency, costs, and other administrative concerns. A theory of neutrality and anonymity pervaded the university's own presentation of itself, but its practices had particular negative effects for those who were newcomers to the institution. ${ }^{24}$

The day of the Fiftieth Anniversary Celebration finally arrived, and faculty, students, devoted alumni, and friends of the university gathered to contemplate the moment. A bouquet of eloquent speeches, decorated with wit and even visual aids, filled the banquet hall. The celebrants mused about the assumptions behind the now-middle-aged reforms, the process of reform, and the actual practices of the contemporary institution they all loved. One distinguished faculty member hazarded speculation about the future. ${ }^{25}$

${ }^{22}$ Cf. Keeton, supra note 18, at 2056 ("The traditional adversary trial is ruled more by tradition than by rule.").

${ }^{23}$ Cf. Subrin, Federal Rules, Local Rules, and State Rules: Uniformity, Divergence, and Emerging Procedural Patterns, 137 U. PA. L. Rev. 1999, 2051 (1989) (noting that "any American procedural model will be modified by the ingenuity of lawyers who have learned to manipulate the rules").

${ }^{24}$ Cf. Carter, supra note 16, at 2182-95 (describing the Federal Rules' disproportionate impact on civil rights litigants); Resnik, The Domain of Courts, 137 U. PA. L. REV. 2219, 2219-20 (1989) (stating that court reforms are political and the resulting rules affect different plaintiffs and defendants in different ways).

${ }^{25}$ Cf. Hazard, Discovery Vices and Trans-Substantive Virtues In the Federal 
Someone else stood up and told a parable about another institution that also had adopted reforms fifty years before and had witnessed unexpected changes. It seemed an odd analogy; the speaker talked of the rules governing litigation in federal courts. She spoke about how innovative rules, now fifty years old, expressed deep tensions between ideals of predictability and discretion, centralization and party control, neutrality and promotion of substantive justice, national uniformity and local responsiveness. She also spoke of how this sort of talk seemed to make the actual impact of the rules difficult to grasp, even while inspiring listeners through the very loftiness of the words. Her listeners, respectful but tired after many long speeches, shouted out, "What's the point?"

She replied:

"1) Reforms go in cycles, especially in America, which has a longstanding tradition of the new. Particularly familiar cycles move between centralization and decentralization, abstraction and contextualization, and uniformity and diversity. Perhaps these mark inevitable points in the journeys of American public and private institutions.

"2) Yet these shifts are not merely the swings of a pendulum, they are the patterns within particular historical contexts of real political struggles.

“3) The real struggles between 1938 and 1988 in America included deliberate efforts to enlarge access in mainstream institutions for people who had been excluded in the past, and to expand economic, cultural, and political participation while retaining the apparent legitimacy of dominant economic, cultural, and political institutions. Various forces of reaction have gained strength, asserted limits, and even imposed cut-backs during the close of this period, while packaging such reactions under generalized concerns for efficiency, managerial success, and a return to normalcy. ${ }^{28}$

"4) No one can evaluate changes in the procedural rules of the game promulgated by basic, mainstream institutions without reference to the substantive goals of those institu-

Rules of Civil Procedure, 137 U. PA. L. REv. 2237, 2244 (1989) ("I doubt that the document discovery rules will be much changed. It is likely, however, that discovery in the future will turn up fewer documents worth discovering.").

${ }^{26}$ See generally L. Friedman, TOTAL Justice 15-23 (1985) (answering charges of a "litigation crisis" by arguing that empirically there is no evidence of a "crisis" and that the charge is used to cover up the modern transformation of substantive law to provide recovery for kinds of harms that victims in the past had to bear themselves). 
tions. What kind of education is promoted by the university, what kind of justice by the courts? These are the questions we must persist in asking when we evaluate procedural reforms: who is helped and who is hurt, whose chances for self-development and for redress are enlarged and whose are compressed by the systems we produce and maintain?

"5) No amount of procedural reform alone will change anything if the culture and traditions of the people who administer and use the institutions remain the same, but the culture and traditions of our people cannot change if the procedures persist in condoning and rewarding mutual distrust, competition, and nastiness."

The speaker seemed to want to end on a happier note and reached for comic words, but found only these, from Woody Allen: "More than any other time in history, mankind faces a crossroads. One path leads to despair and utter hopelessness. The other, to total extinction. Let us pray we have the wisdom to choose correctly."27

As the celebrants packed up their bags, tucked in their shirts, and staggered out from the anniversary party, they passed by some workers who were renovating the building. The workers had constructed an elaborate and elegant scaffold around the building, and the celebrants lauded their work. One of the workers looked surprised, and said:

"Well, there is an art to building a good scaffold, one that is sturdy, and flexible. It must let us haul the paint up from the bottom, and reach the top. But it's really not that important. Come back and see what you think of the building when we're done. And maybe when you next celebrate, we'll also be back." 
